\title{
Education for Entrepreneurship during Industrial Revolution 4.0: Opportunities and Challenges
}

\begin{abstract}
Entrepreneurship 4.0 can be seen as a new type of technological entrepreneurship, based on advanced technologies (e.g. the internet of things, artificial intelligence) which should help to improve the productivity and innovativeness of the Polish economy. However, the development of Economy 4.0 is associated with certain dilemmas and even with the destruction of the existing 'rules' of socio-economic life. The purpose of the article is to identify the opportunities and challenges of entrepreneurship development in the context of the Fourth Industrial Revolution, regarding the role of education in this process. Thus, an explorative study was carried out based on the literature and secondary data (2015-2019) analysis (e.g. GUESS, PISA, GEM). The technical capabilities of Polish engineers and IT specialists can facilitate the development of innovative entrepreneurship 4.0. However, intensive educational efforts are required in order to improve the soft skills of the new generations $(\mathrm{Y}, \mathrm{Z})$, such as communication skills, relationship building and interdisciplinary team cooperation. Additionally, the role of education should concentrate on shaping ethical attitudes and social responsibility for the consequences of innovations introduced on the market.
\end{abstract}

Keywords: Economy 4.0; education; entrepreneurship; institutions

Received: 30 October 2019

Accepted: 25 March 2020

\section{Suggested citation:}

Nowak, H. (2020). Education for Entrepreneurship during Industrial Revolution 4.0: Opportunities and Challenges. Przedsiębiorczość - Edukacja [Entrepreneurship - Education], 16(1), 74-84. doi: $10.24917 / 20833296.161 .6$

\section{Introduction}

Discussion of the role of education in developing entrepreneurial competencies, transmitted content and teaching methods has been going on for many years. Attempts are also being made, though few, to assess the effects of formal entrepreneurship education. Due to the interdisciplinary nature of the problem, universal solutions have not yet been 
found in this area. Meanwhile, under the influence of technological progress (including new technological ideas within so-called Industry 4.0: artificial intelligence, virtual reality, etc.) there has been a revolutionary change in the business and legal environment, but also a significant cultural shift that has not been fully understood. The latter is manifested in new lifestyles, jobs, communication methods, values and respected social norms. The cultural change primarily affects the youngest generations (Y, Z), which have grown up in the era of the digital revolution and the coming years will increasingly influence the labour market, both on the demand and supply sides. The new conditions require new competencies from future entrepreneurs and employees. The question, therefore, arises to what extent the formal education system can support the learning processes of prospective employees and entrepreneurs operating in the new economy. However, it seems that in the face of such significant technological change, the need for entrepreneurship education concerns a much broader context - including attitudes, cognitive processes and the competencies of potential recipients of products and services offered based on advanced technological achievements. Therefore, the article uses a broad approach to education for entrepreneurship 4.0. It takes into account its significant role in balancing the changes taking place in various dimensions of socio-economic life and fills the "cognitive gap" that has occurred along with the dynamic development and implementation of highly advanced technologies (Kowalczyk, 2019).

The issue of processes referred to as the Fourth Industrial Revolution in the context of education and entrepreneurship development is a new research area. The study is exploratory. The article aims to identify the opportunities and challenges awaiting educational institutions in the face of socio-cultural, business and legal change caused by the Fourth Technological Revolution. The article uses methods of analysis and criticism of the literature as well as the study of existing data from national and international reports defining professional predispositions and the entrepreneurship of the youngest generations. The considerations have been focused around Polish experience and institutional conditions with references to a broader international context, in particular the European one.

The first part of the article specifies the concept of entrepreneurship and the theoretical background adopted for analysis, taking into account the sources and the specificity of this phenomenon developing in the so-called 'New Economy'. The next part presents dilemmas and the conditions for the development of a 4.0 economy, followed by attempts to identify the most critical opportunities and challenges for education in a wider sense that are associated with stimulating the growth of entrepreneurship 4.0.

\section{The concept and nature of entrepreneurship in the New Economy}

Undertaking the issues of entrepreneurship in research activity is associated with the need to define this concept and enter it into the theoretical framework adopted for analysis. Literature studies indicate a variety of approaches and research methods. On the one hand, this reveals the multi-faceted nature of this phenomenon, on the other, confirms the immaturity of entrepreneurship as an academic discipline and the lack of a unified entrepreneurship theory (Gaweł, 2013; Kurczewska, 2013; Piecuch, 2010).

Broadly speaking, entrepreneurship is treated as an attitude, behaviour or competence necessary in every area of life (Piecuch, 2010; Piróg, 2015; Rachwal, 2019). A narrower understanding of this phenomenon concerns the definition of entrepreneurship 
as the economic activity of a human being - an entrepreneur who creates new value in the economy (Cieślik, 2014). The effect of entrepreneurial activity can be the creation of a new enterprise and its development (process approach), as well as the introduction of innovations of different nature, e.g. improved products, production methods, processes or organisational solutions (Schumpeter's approach) (Gawel, 2013).

Entrepreneurial processes which are undertaken at the microeconomic level become the basis for development and the driving force of economic growth, hence the links between entrepreneurship and the economy are undeniable. Despite this, the role of the entrepreneur in the economy has been neglected in mainstream economics since the $20^{\text {th }}$ century (Kurczewska, 2013).

Creating a New Economy based on knowledge and innovation (Borowiecki, Dziura, 2016) is accompanied by changes caused by technological progress which have been particularly intensifying in recent years under the influence of the Fourth Industrial Revolution. Such concepts as digitisation, computerisation, automation, information society, knowledge-based economy and technological entrepreneurship have been the subject of interest of researchers and theoreticians from various fields for many years (Cieślik, 2014; Zioło, 2008; Zioło, Rachwał, 2009). However, the economic development 4.0 is associated with the use of technologies that enable personalisation of production such as the internet of things, 3D printing, virtual and augmented reality (Jaworowska, Piątek, 2019) whose far-reaching impact on the current institutional order cannot be fully anticipated at this stage. It seems that "new" entrepreneurship based on "smart" technologies initiated in industry 4.0 will be a specific example of the idea of Schumpeter's "creative destruction" breaking down the existing rules of many areas of socio-economic, personal and professional life.

Challenges and dilemmas related to the development of the economy 4.0, including entrepreneurship 4.0, have recently been taken up in the literature. In this context, it is also necessary to reflect on the role of education in the new conditions created by the Fourth Technological Revolution. In the face of profound institutional changes related to the need to modify the law, changes taking place in the sphere of informal institutions norms and values functioning in society, as well as in shaping people's cognitive processes, the role of education should manifest itself, among others in alleviating inconsistencies and the disturbed balance between the areas indicated. The "cognitive gap" resulting from the technological revolution (Kowalczyk, 2019), without the multidimensional support of educational institutions, may negatively affect the entrepreneurial processes taking place in the economy 4.0, both on the side of future entrepreneurs, creators of new enterprises based on modern technologies, and potential users and recipients of new solutions implemented on the market in the form of innovative products and services. The source of failure may be a lack of trust, misunderstanding of the processes taking place, fear of significant interference in the lives of members of society by eliminating existing rules of functioning and creating new ones at the socio-economic level, despite the expected positive effects in terms of improving the competitiveness and innovation of enterprises and the economy.

An analysis of challenges and opportunities in the area of education related to the development of entrepreneurship in the spirit of Schumpeter's "creative destruction" should be preceded by the characteristics of fundamental dilemmas and determinants of economic development 4.0. 


\section{Dilemmas and determinants of economic development 4.0}

The Fourth Technological Revolution was initiated in the industry (smart factories) from where it spread to other areas of the economy (e.g. intelligent buildings, intelligent mobility and transport, intelligent energy) (Cellary, 2019).

Different levels of development of individual technologies and their possible applications, opportunities and threats are considered in many scientific, advisory and political bodies. For example, the use of technologies such as artificial intelligence, virtual and augmented reality and blockchain technology in the creative sector of the economy related to art, fashion, music and film, is considered in both a positive and negative context. Attention is drawn to powerful tools for influencing people (including disinformation in social media, enhanced by algorithms), their impact on lifestyle changes, and even the acquisition of more and more private user data (World Economic Forum, 2018).

According to Cellary (2019), the distinguishing features of the economy 4.0 result not only from the digitisation of the entire value chain and the pursuit of improving productivity, innovation and adaptation to customer needs. They also result from the primary goal of industry 4.0 which is to provide cyber-physical systems with autonomy in making decisions. It is possible thanks to the intensive flow of data and the use of artificial intelligence techniques for their processing, taking into account the change in the role of people in the whole process. According to this author, essential non-technological challenges related to the development of industry 4.0 relate to future employees, correction of errors in the sophisticated software used in cyber-physical systems, in particular those based on Big Data, as well as determining the responsibility for possible errors and their consequences (Cellary, 2019).

In addition to the widely discussed problem of developing employees' competencies tailored to the new challenges on the labour market, the literature draws attention to, among others, the question of digital maturity, cybersecurity and changes in the business environment (Nosalska, Gracel, 2019; Kohnová, Papula, Salajová, 2019). The latter aspect is related to the organisation and management of enterprises. It also concerns the creation of new enterprises, and the introduction of innovations in existing business models (Ibarra et al., 2018). Particularly noteworthy is the problem of differences between generations, including the values of the younger generation (millennials) which are likely to significantly influence the shaping of the business environment in industry 4.0 (Črešnar, Jevšenak, 2019).

The financial sector is one of the critical and sensitive areas, hence many institutions, including the European Central Bank, are taking measures to assess the potential of blockchain technology in creating innovation in a new type of transaction in the digital economy (Bott, Milkau, 2017). An important issue is the aspects related to the preparation of an appropriate regulatory framework and government initiatives aimed at supporting industry 4.0 (Liao et al., 2017), including regulations encouraging cooperation between universities and enterprises to stimulate innovation in the economy (Demchenko, 2017). Besides, attention is paid to issues of trust and the creation of an organisational culture conducive to ethical activities (Kiepas, 2017; Nosalska, Gracel, 2019).

One of the underlying conditions for the development of entrepreneurship 4.0 is the digitisation of Polish society and its economy. Table 1 presents selected indicators illustrating the level of digitisation of the Polish economy and society against other European 
countries based on components of the Digital Economy and Society Index (European Commission, 2019a).

The presented data point to the distant position of Poland against other European Union countries in this area. So far, the percentage of Polish non-financial enterprises employing ten or more employees that use data processing techniques (Big Data and cloud computing) is small. Particularly apparent is the discrepancy in this area in relation to Finland as a leader in the implementation of the indicated solutions. Also, the percentage of people with basic and higher than basic digital skills, and Polish Internet users using online courses, places Poland below the average in the European Union. The percentage of ICT specialists employed in the Polish economy also seems insufficient.

Table 1. Selected components of the Digital Economy and Society Index

\begin{tabular}{|l|c|c|c|c|c|}
\cline { 2 - 6 } \multicolumn{1}{c|}{} & Finland & Spain & Czechia & Poland & EU \\
\hline $\begin{array}{l}\text { At least basic digital skills (\% of the population } \\
\text { aged 16-74) }\end{array}$ & 75.60 & 54.80 & 59.80 & 46.40 & 57.20 \\
\hline $\begin{array}{l}\text { Digital skills higher than basic } \\
\text { (\% of the population aged 16-74) }\end{array}$ & 45.20 & 31.60 & 24.10 & 21.10 & 31.20 \\
\hline Internet users (\% of the population aged 16-74) & 92.60 & 82.50 & 83.80 & 74.80 & 83.10 \\
\hline $\begin{array}{l}\text { Using online courses (\% of internet users in the } \\
\text { last 3 months) }\end{array}$ & 16.90 & 14.80 & 3.83 & 5.04 & 8.79 \\
\hline ICT specialists(\% of employees aged 15-74) & 6.80 & 2.90 & 3.60 & 2.80 & 3.70 \\
\hline $\begin{array}{l}\text { Use of Big Data (\% of enterprises without the } \\
\text { financial sector, 10 and more employees) }\end{array}$ & 19.00 & 10.70 & 8.09 & 7.89 & 12.30 \\
\hline $\begin{array}{l}\text { Use of cloud computing (\% of enterprises } \\
\text { without the financial sector, 10 and more } \\
\text { employees) }\end{array}$ & 50.20 & 16.30 & 15.50 & 6.67 & 17.80 \\
\hline
\end{tabular}

Source: European Commission, Digital Scoreboard 2019

Dilemmas and determinants of economic development 4.0 in the context of stimulating entrepreneurial activity can be expressed in several questions related to the following areas:

- political and legal conditions (directions of EU economic policy, member states, law): should the law strengthen or limit specific manifestations of entrepreneurship and innovation significantly interfering with the current principles of social life?

- industry interests: how are a competitive position and the bargaining power of enterprises changing in the digital and modern technologies industry, and what impact do these changes have on the transformation of other industries, sectors of the economy, e.g. the financial sector?

- social interest, social legitimacy (older generations vs generations Y, Z): does society accept the implementation of solutions based on the advanced use of digital technologies and the processing of large amounts of data? Is there public confidence in entrepreneurship based on technology 4.0 ?

- the development of competencies of pupils, students and other members of society: do representatives of various social groups have sufficient competencies to benefit from the achievements of the economy 4.0 ? 
The rest of the article focuses on deepening the issues related to the role of education in the process of stimulating entrepreneurship 4.0. It is based on the conviction that the educational pillar of the institutional environment will have a very significant, if not the most important, impact on the success and achievement of the expected results of socio-economic development.

Opportunities and challenges in the context of education for entrepreneurship in the conditions of the Fourth Technological Revolution

In broad terms of entrepreneurship education 4.0, there are a few basic questions about who it should be addressed to, what competencies to develop, what content to undertake, and what methods to convey it to.

Entrepreneurship 4.0 should be taught, to varying degrees, to all social groups. The most important is the problem of training the competencies of future entrepreneurs and innovators setting up new enterprises and introducing new products and services to the market. Furthermore, there is the issue of digital competencies and the cognitive abilities of potential employees and users of the proposed solutions as well as teachers and lecturers who should shape proactive attitudes and entrepreneurial intentions of school and university students in new technological conditions.

Improving the innovativeness of the Polish economy based on technologies related to the Fourth Technological Revolution will largely depend on the intentions, attitudes and aspirations of the younger generations. According to The Global University Entrepreneurial Spirit Students' Survey, Polska, the entrepreneurial intentions of Polish students were expressed by $7 \%$ of respondents concerning the period immediately after graduation. In comparison, declarations regarding the desire to run their own business within five years after graduation concerned $40 \%$ of respondents (Lewandowska et al., 2017). Global Entrepreneurship Monitor research shows an improvement in the perception of entrepreneurship as a good career option. While in 2013, 66.81\% of respondents from Poland gave an affirmative answer, in 2018 , this option was attractive to $85.86 \%$ of respondents (GEM, 2019). However, the situation in terms of innovation in Polish enterprises is less favourable, in particular in the SME sector. According to the European Innovation Scoreboard, Poland is one of a group of moderate innovators, although it ranks fourth from the end (European Commission, 2019b).

Therefore, one of the challenges of entrepreneurship education is to stimulate the innovative activity of the youngest generation. There is also significant doubt as to whether people from generation Y (millennials) and younger will be prepared to take over the role of leaders in the economy, even in the dimension of entrepreneurship and innovation associated with the Fourth Technological Revolution. On the one hand, the natural ability of this generation to use information technologies, their creativity, energy, willingness to express themselves and thinking outside the box is emphasised. On the other hand, there is a strong need for praise and constant feedback (Espinoza, Ukleja, 2018). In the Deloitte Global Millennial Survey (2019), as many as 79\% of representatives of generation Y in Poland declare the knowledge and skills required by the labour market shaped by industry 4.0.

On the other hand, a similar percentage of respondents are afraid of online fraud and how organisations obtain personal data ( $79 \%$ and $78 \%$ respectively). A high rate of responses demonstrating millennials' lack of confidence in solutions based on digitisation and data 
processing that characterise industry 4.0 suggests that the sense of security will become one of the main determinants of entrepreneurship development based on technologies 4.0. Not only cognitive processes and the risk assessment of starting a business, and the responsibility for implemented solutions, on the side of future entrepreneurs, but also the desire to use such solutions on the side of users, will have a considerable impact on the success or failure of the assumed effects of entrepreneurship development in the economy 4.0.

On the one hand, the answer of the education in this field should be that for specialists in the field of security and data protection in the world of comprehensive digitisation. Education should also spread awareness among pupils, students, future entrepreneurs and through the whole of society regarding the possible threats resulting from the application and use of the latest technologies. Besides, great emphasis should be placed on shaping ethical behaviour in a spirit of responsibility for the effects of solutions introduced to the market. As the first examples show (e.g. accidents involving autonomous vehicles), the implemented solutions can significantly disrupt the existing 'rules' of social life, which often requires a belated reaction of legislative authority and difficult decisions for the judiciary. This is, among others, due to the fact that, unlike other types of economic activity, entrepreneurship 4.0 is associated with a change in the role of a person who becomes the supervisor of autonomous systems controlled by artificial intelligence, which is an even more significant challenge than before (Cellary, 2019). Education should, therefore, significantly increase the legal awareness of the public concerning regulations related to entrepreneurship based on technology 4.0.

Preparing future entrepreneurs and employees to cooperate with machines and robots is one of the biggest challenges of the education system in the coming years (Cellary, 2019). Attention is also paid to the new role of engineers as change leaders (Smart Industry Polska, 2019). According to L.A. Gibson and W.A. Sodeman (2014), advanced technical skills are an essential but insufficient factor for success in modern organisations. Particular attention is paid to the shortage of soft skills, such as in communication, critical thinking and problem-solving, as well as building and managing relationships (Gibson, Sodeman, 2014). Understanding, analysing and structuring data, interdisciplinary thinking, cooperation and the ability to behave ethically and trustworthy become essential skills (Nosalsk, Gracel; 2019, Kiepas, 2017; Demchenko, 2017). According to Cellary, the New Economy needs people who understand how to control artificial intelligence, and who will be able to prevent mistakes with enormous consequences for society. However, despite the autonomy of machines, understanding and creativity will always remain the domain of humanity (Cellary, 2019).

Polish youth get quite good results in the International Student Skills Assessment Program, which place Polish 15-year-olds in the following places among European Union countries: reasoning in natural sciences $-7^{\text {th }}$ place, reasoning in reading and interpretation $-4^{\text {th }}$, mathematics $-6^{\text {th }}$ (PISA, 2015). Education in the STEAM subjects (Science, Technology, Engineering, Art, Mathematics), might help develop competencies necessary for entrepreneurship 4.0. STEAM encourages learners to be more involved in the learning process through the independent search for solutions and helps develop creativity, cooperation, design thinking, analysis and critical thinking skills, e.g. through workshops in the basics of programming, 3D printing and robotics (Centralny Dom Technologii, 2019). The basis of success seems to be the integration of skills and knowledge from various areas and fields. Thanks to the attractiveness of the message, it leads to the creation 
of innovative ideas. An example of an educational toy for the youngest as an education tool in this trend is the Photon robot created by young Polish engineers from the Bialystok University of Technology, who were in the " 30 before 30 " ranking created by Forbes monthly (Białystok naszaemiasto.pl, 2018; Photon, 2019).

Table 2 presents the opportunities and challenges related to education for entrepreneurship 4.0, identified directly based on the analysed literature or, indirectly, based on the indicated dilemmas and determinants of economic development 4.0. On this basis, it can be assumed that the Polish economy has the potential to develop entrepreneurship based on advanced technologies 4.0. Still, without a comprehensive support policy and actions of educational institutions, it will not be possible to fully use the existing intellectual resources to stimulate the innovation in the economy in a broader dimension.

Table 2. Key aspects of education for entrepreneurship 4.0 - opportunities and challenges

\begin{tabular}{|c|c|}
\hline Opportunities & Challenges \\
\hline $\begin{array}{l}\text { - good results of Polish teenagers in the } \\
\text { International Student Assessment Program } \\
\text { (reasoning in reading, mathematics) } \\
\text { - } \text { high level of technical education in Poland } \\
\text { qualified engineers, IT specialists, winners } \\
\text { in national and international competitions } \\
\text { for young engineers } \\
\text { - the creativity of representatives of the young } \\
\text { generations (Y, Z) combined with digital } \\
\text { and technological skills } \\
\text { - entrepreneurial intentions of Polish } \\
\text { students from the perspective of five years } \\
\text { after graduation } \\
\text { - perception of entrepreneurship as a good } \\
\text { career option } \\
\text { - stimulating academic entrepreneurship } \\
\text { at technical universities } \\
\text { - using } 4.0 \text { technology in the process of } \\
\text { training entrepreneurial and innovative } \\
\text { attitudes and activities } \\
\text { - strengthening interdisciplinarity by } \\
\text { developing STEAM skills }\end{array}$ & $\begin{array}{l}\text { - educating more ICT specialists, in particular } \\
\text { in the field of data security and protection, } \\
\text { able to understand processes occurring } \\
\text { in cyberphysical systems } \\
\text { - developing soft skills of the young } \\
\text { generation, as well as their cooperation } \\
\text { and communication skills } \\
\text { - integration of technical expertise } \\
\text { with managerial, entrepreneurial and } \\
\text { communication skills } \\
\text { - creating opportunities for cooperation } \\
\text { and building interdisciplinary teams } \\
\text { between university students of various } \\
\text { profiles (e.g. natural, technical, economic) } \\
\text { - strengthening collaboration between the } \\
\text { university teachers of different types } \\
\text { of universities (exchange of knowledge } \\
\text { and experience) } \\
\text { - enhancing education and competencies } \\
\text { in modern technologies among school } \\
\text { and university teachers } \\
\text { - developing digital competencies of older } \\
\text { generations, bridging the gap between } \\
\text { generations in this respect } \\
\text { - shaping the attitude of responsibility } \\
\text { and professional ethics } \\
\text { - strengthening elements of education } \\
\text { in the field of law and regulations regarding } \\
\text { the implementation of technology } 4.0, \\
\text { and liability for mistakes with enormous } \\
\text { consequences for the society } \\
\text { - integration of knowledge from various } \\
\text { areas: technology, law, economics, } \\
\text { sociology, ethics } \\
\text { - strong interdisciplinary cooperation, } \\
\text { building trust between partners (universities } \\
\text { with different profiles and enterprises) }\end{array}$ \\
\hline
\end{tabular}

Source: author 
Summary

The article adopts an approach according to which education for entrepreneurship 4.0 is not limited to training attitudes and entrepreneurial competencies, but in a broad sense covers many activities allowing the integration of knowledge and skills in various fields. Entrepreneurship 4.0 can be seen as a new dimension of technological entrepreneurship (technology start-ups), knowledge-based entrepreneurship, academic entrepreneurship, or it can be equated with innovation associated with the use of the achievements of the Fourth Industrial Revolution.

Education for entrepreneurship 4.0 should take into account the specificity of this phenomenon at all stages of the entrepreneurial process, from shaping entrepreneurial attitudes, intentions and motivations, through identifying and assessing business opportunities, gathering resources and launching a product or service on the market. All these stages are determined by digital transformation but in particular, the use of technologies related to the integration of cyber-physical systems and the processing of large amounts of user data. The sources of entrepreneurship 4.0 are technology, specialist knowledge, digital competencies, including programming and algorithm creation capabilities, as well as implemented innovations which may also be the result of deeper cooperation between universities and enterprises.

Shaping ethical attitudes and building conditions for cooperation on many levels between institutions, students and teachers of various professional profiles - is a particularly important role of education. Collaboration and integration of knowledge in multiple fields (technical, business, legal, etc.) will allow better use of resources and opportunities related to the development of entrepreneurship based on technology 4.0.

The main limitation of the study is its general nature resulting from an analysis of dispersed secondary data. The study does not give a clear picture of the predisposition of the young generation to entrepreneurship in the conditions of the Fourth Technological Revolution. Further research in this area should focus on the systematic analysis of the competencies and intentions of the youngest generations towards undertaking entrepreneurship 4.0, as well as the barriers and restrictions to the development of this phenomenon in the social sphere.

In the face of dilemmas related to the creation of the economy 4.0, and significant changes in the business, legal and socio-cultural environment caused by technological progress, education will play a critical role in alleviating the negative consequences of transformations beyond the possibilities of human cognition. Therefore, on the one hand, it will be a factor that will enable progress by educating future entrepreneurs and innovators. On the other, it will allow adaptation to the new socio-economic conditions caused by the Fourth Technological Revolution.

\section{References}

Białystok naszemiasto.pl. (2019, 25 października). Twórcy Photona $w$ rankingu miesięcznika Forbes. Najzdolniejsi przed 30!. Retrieved from: https://bialystok.naszemiasto.pl/tworcy-photona-w-rankingu-miesiecznika-forbes-najzdolniejsi/ar/c3-4824077

Borowiecki, R., Dziura, M. (2016). Nowa gospodarka - aspekty wiedzy i innowacji. Przegląd Organizacji, 5, 9-16. 
Bott, J., Milkau, U. (2017). Central bank money and blockchain: A payments perspective. Journal of Payments Strategy \& Systems, 11(2), 145-157.

Cellary, W. (2019). Non-Technical Challenges of Industry 4.0. In: L.M. Camarinha-Matos, H. Afsarmanech, D. Antonelli (Eds), Collaborative Networks and Digital Transformation, IFIP Advances in Information and Communication Technology, 568, 3-10. IFIP-Springer. doi: 10.1007/978-3-030-28464-0

Centralny Dom Technologii. (2019, 24 October). Retrieved from: https://cdt.pl/

Cieślik, J. (2014). Przedsiębiorczość. Polityka. Rozwój. Warszawa: Wydawnictwo Akademickie SEDNO.

Črešnar, R., Jevšenak, S. (2019). The Millennials’ Effect: How Can Their Personal Values Shape the Future Business Environment of Industry 4.0? Naše Gospodarstvo/Our Economy, 65(1), 57-65. doi: 10.2478/ngoe-2019-0005

Deloitte Global Millennial Survey (2019, 24 October). Retrieved from: https://www2.deloitte.com/global/en/pages/about-deloitte/articles/millennialsurvey.html.

Demchenko, O.P. (2017). The state regulation mechanism of cooperation between higher educational institutions and business. Scientific bulletin of Polissia, 1(9), 210-217.

Espinoza, C., Ukleja, M. (2018). Zarządzanie milenialsami. Warszawa: Wydawnictwo Naukowe PWN.

European Commission (2019a, 24 October). The Digital Economy and Society Index (DESI). Retrieved from: https://ec.europa.eu/digital-single-market/en/desi

European Commission. (2019b, 24 October). European Innovation Scoreboard. Retrieved from: https:// ec.europa.eu/growth/industry/innovation/facts-figures/scoreboards_en

Gaweł, A. (2013). Proces przedsiębiorczy. Tworzenie nowych przedsiębiorstw. Warszawa: Difin.

Gibson, L.A., Sodeman, W.A. (2014). Millennials and Technology: Addressing the Communication Gap in Education and Practice. Organization Development Journal, 34(4), 63-75.

GEM. (2019, 25 października). Global Entrepreneurship Monitor. Retrieved from: https://www.gemconsortium.org/

Ibarra, D., Ganzarain, J., Igartua, J.I. (2018). Business model innovation through Industry 4.0: A review. Procedia Manufacturing, 22, 4-10.

Jaworowska, M., Piątek, Z., (2019, 24 October). Przemysł 4.0 - technologie przyszłości. Retrieved from: https://automatykab2b.pl/temat-miesiaca/47534-przemysl-4-0-technologie-przyszlosci

Kiepas, A. (2017). Ewolucja wartościowania techniki w obliczu różnych wyzwań - od zwrotu normatywnego do przemysłu 4.0. Zeszyty Naukowe Politechniki Ślaskiej, Organizacja i Zarządzanie, 112, 193-205.

Kohnová, L., Papula, J., Salajová, N. (2019). Internal factors supporting business and technological transformation in the context of Industry 4.0. Business: Theory and Practice, 20, 137-145.

Kowalczyk, M. (2019). Cyfrowe państwo. Uwarunkowania i perspektywy. Warszawa: Wydawnictwo Naukowe PWN.

Kurczewska, A. (2013). Przedsiębiorczość (jako proces wspótoddziaływania sposobności i intencji przedsiębiorczych). Warszawa: Polskie Wydawnictwo Ekonomiczne.

Lewandowska, A., Chrostowska-Siwek, I., Tylczyński, Ł. (2017). Global University Entrepreneurial Spirit. Students' Survey 16'. Poland. Retrieved from: http://www.guesssurvey.org/resources/nat_2016/ GUESSS_Report_2016_Poland.pdf

Liao, Y., Deschamps, F., de Freitas Rocha Loures, E., Pierin, Ramos, L.F. (2017). Past, present and future of Industry 4.0 - a systematic literature review and research agenda proposal. International Journal of Production Research, 55(12), 3609-3629. Retrieved from: http://dx.doi.org/10.1080/00207543.2 017.1308576

Nosalska, K., Gracel, J. (2019). Kompetencje pracowników a kształtowanie dojrzałości cyfrowej przedsiębiorstw w kontekście Przemysłu 4.0. Zarządzanie Zasobami Ludzkimi, 3-4(128), 73-86.

Photon. (2019, 25 October). Retrieved from: https://photonrobot.com/pl

Piecuch, T. (2010). Przedsiębiorczość. Podstawy teoretyczne. Warszawa: Wydawnictwo C.H. Beck.

Piróg, D. (2015). Kompetencje z zakresu przedsiębiorczości: rozważania teoretyczne i ich ilustracje w obszarze szkolnictwa wyższego. Przedsiębiorczość - Edukacja [Entrepreneurship - Education], $11,364-376$. 
PISA. (2015). Program Międzynarodowej Oceny Umiejętności Uczniów. Retrieved from: http://www.ibe. edu.pl/pl/projekty-miedzynarodowe/pisa

Rachwał, T. (2019). Przedsiębiorczość jako kompetencja kluczowa w systemie edukacji. W: T. Rachwał (red.), Kształtowanie kompetencji przedsiębiorczych. Warszawa: Wydawnictwo FRSE, 16-34.

Smart Industry Polska. (2019). Inżynierowie $w$ dobie czwartej rewolucji przemysłowej. Raport $z$ badań. Warszawa: Ministerstwo Przedsiębiorczości i Technologii/Siemens. Retrieved from: https://publikacje.siemens-info.com/pdf/594/Raport\%20Smart\%20Industry\%20Polska\%202019.pdf

World Economic Forum. (2018). Creative Disruption: The impact of emerging technologies on the creative economy, White Paper in collaboration with McKinsey \& Company. Retrieved from: http://www3. weforum.org/docs/39655_CREATIVE-DISRUPTION.pdf

Zioło, Z. (2008). Ekonomiczne i społeczne uwarunkowania rozwoju gospodarki opartej na wiedzy. Przedsiębiorczość - Edukacja [Entrepreneurship - Education], 4, 12-23.

Zioło, Z., Rachwał, T. (red.). (2009). Rola przedsiębiorczości w kształtowaniu społeczeństwa informacyjnego. Przedsiębiorczość - Edukacja [Entrepreneurship - Education], 5.

Hanna Nowak, PhD in Economics from the Poznań University of Economics and Business (Poland). Assistant professor in the Institute of Economics (Department of Microeconomics) at the Poznań University of Economics and Business. Her academic interests include entrepreneurship, entrepreneurship education, factors of survival for SMEs, and the institutional environment for company creation and development.

ORCID: https://orcid.org/0000-0002-4760-3840

\section{Adres/Address:}

Uniwersytet Ekonomiczny w Poznaniu

Instytut Ekonomii

Katedra Mikroekonomii

al. Niepodległości 10

61-875 Poznań, Poland

e-mail: hanna.nowak@ue.poznan.pl

The project was financed under the program of the Minister of Science and Higher Education under the name "Regional Initiative of Excellence" in the years 2019-2022. Project number: 004/RID/2018/19, funding: PLN 3000000 . 